\title{
Clinical complications in patients with severe cervical spinal trauma: a ten-year prospective study
}

\author{
Complicações clínicas em pacientes com trauma raquimedular cervical grave: estudo \\ prospectivo de dez anos
}

Egmond Alves Silva Santos ${ }^{1}$, Wenner Jorzino Santos Filho', Lucas Loss Possatti', Lia Rita Azeredo

Bittencourt², Emílio Afonso França Fontoura' ${ }^{1}$ Ricardo Vieira Botelho ${ }^{1,3}$

\begin{abstract}
Objective: To determine the complications due to severe acrescentar sigla após o nome (CST). Methods: Between 1997 and 2006,217 patients (191 men and 26 women) were prospectively evaluated. The mean age was $36.75 \pm 1.06$ years. Results: Forty-five percent of the patients had medical complications. The most important risk factor was alcoholic beverage use. The most important associated injury was head trauma (HT). Patients with American Spine Injury Association (ASIA) A or B had a 2.3-fold greater relative risk of developing complications. Thirty-three patients (15.2\%) died. Patients with neurological deficit had a 16.9-fold higher risk of death. There was no influence of age and time between trauma and surgery on the presence of complications. Conclusions: Of the patients, $45 \%$ had clinical complications and $7.5 \%$ had associated injuries; pneumonia was the most important complication; patient age and time between trauma and surgery did not influence the development of medical complications; neurological status was the most important factor in determining morbidity and mortality.
\end{abstract}

Key words: wounds and injuries, spine, cervical spine trauma.

\section{RESUMO}

Objetivo: Identificar complicações decorrentes do trauma raquimedular cervical grave. Métodos: Avaliação prospectiva de 217 pacientes (191 homens e 26 mulheres) entre 1997 e 2006, com média de idade de 36,75 1,06 anos. Resultados: Houve complicações em 45\% dos pacientes. 0 fator de risco mais importante foi ingestão de bebida alcoólica. Trauma craniano foi a associação mais frequente. Pacientes com classificação A ou B da American Spine Injury Association (ASIA) tiveram 2,3 vezes maior chance de complicações. Faleceram 33 pacientes (15,2\%), sendo a chance de óbito 16,9 vezes maior naqueles com déficit neurológico. Não houve influência da idade ou do tempo decorrido entre o trauma e a cirurgia. Conclusões: Dos pacientes, 45\% apresentaram complicações e 7,5\% apresentaram traumas associados; pneumonia foi a principal complicação clínica; a idade dos pacientes e o tempo entre o trauma e a cirurgia não influenciaram na frequência de complicações; o status neurológico após o trauma foi o fator de risco mais importante na determinação de morbidade e mortalidade.

Palavras-Chave: ferimentos e lesões, coluna vertebral, trauma cervical.

Spinal trauma (ST) remains an important cause of morbidity and mortality ${ }^{1,2}$ despite recent advances in the treatment of complications. The number of patients with ST has been found to range from 900 to 1200 per million persons per year ${ }^{3-5}$. About 45 to $60 \%$ of these individuals have cervical spinal trauma (CST), which is associated with high rates of morbidity and mortality, demanding prolonged treatment and higher costs ${ }^{5-10}$.

The high rate of complications observed in patients with ST is due to forces involved in trauma or to the neurological status of these patients ${ }^{11}$. The rates of complications have been found to vary among studies ${ }^{12-14}$. We have evaluated the clinical complications and adjuvant risk factors for severe CST, and the association between neurological status and presence of complications in patients from the north area of São Paulo city, Brazil, treated at a single institution between 1997 and 2006.

\section{METHODS}

\section{Patients}

We prospectively evaluated all patients with severe CST treated during the years 1997 through 2006 in an area defined

\footnotetext{
${ }^{1}$ Conjunto Hospitalar do Mandaqui, São Paulo SP, Brazil;

${ }^{2}$ Disciplina de Medicina do Sono, Universidade Federal de São Paulo (UNIFESP), São Paulo SP, Brazil;

${ }^{3}$ Pós-graduação do Instituto de Assistência Médica ao Servidor Público Estadual (IAMSPE), Hospital do Servidor Público Estadual, São Paulo SP, Brazil.

Correspondence: Ricardo Vieira Botelho; Avenida Dr. Altino Arantes, 390 / apto. 81; 04042-000 São Paulo SP - Brasil; E-mail: vieira.botelho@uol.com.br

Conflict of interest: There is no conflict of interest to declare.

Received 05 October 2011; Received in final form 11 December 2011; Accepted 21 December 2011
} 
by the São Paulo State Health Department as DIR IV, at the Franco da Rocha region, with a population of approximately 2,148,835 inhabitants (São Paulo City Health Department 2006 data). This study was approved by the ethics committee on research (Instituto de Assistência aos Servidores Públicos do Estado de São Paulo - IAMSPE). All patients with severe CST, defined as trauma with or without neurological deficit and/or mechanical instability ${ }^{15}$, were accompanied during hospitalization and their data were registered in the database (Table 1). Patients treated exclusively in the emergency room and discharged, as well as patients suffering severe CST who died at the trauma scene or in the emergency room, were excluded. The hospitals in the area of reference are: Conjunto Hospitalar do Mandaqui, Hospital e Maternidade Dr. M. A. da Silva - Cachoeirinha, Pronto Socorro Municipal Freguesia do Ó, Pronto Socorro Municipal Perus, Hospital Municipal Dr. José Soares Hungria - Pirituba, Pronto Socorro Municipal Santana, Hospital Municipal José Storopolli, Pronto Socorro Municipal Vila Maria Baixa, Pronto Socorro Municipal Bandeirantes, Hospital Municipal Prof. Mario Degni and Pronto Socorro Municipal Lapa.

\section{Variables assessed}

Demographic variables included patient age and sex; clinical variables included cause of trauma, adjuvant factors predisposing for trauma (violence and alcohol abuse), clinical

Table 1. Data of 217 patients with severe cervical spine trauma.

\begin{tabular}{lcc} 
ASIA & $\mathrm{n}$ & $\%$ \\
A & 62 & 28.6 \\
B & 15 & 6.9 \\
C & 13 & 6 \\
D & 22 & 10.1 \\
E & 95 & 43.8 \\
Central cord syndrome & 10 & 4.6 \\
Gender & & \\
Male & 191 & 88.0 \\
Female & 26 & 12.0 \\
Risk factor & 62 & 28.6 \\
Alcohol beverage & 36 & 16.6 \\
Violence & 6 & 2.8 \\
Others & 20 & 9.2 \\
Clinical complications & 96 & 44.2 \\
Pneumonia & 32 & 14.7 \\
DVT/PE & 7 & 3.2 \\
Urinary tract infection & 5 & 2.3 \\
Wound infection & 9 & 4.1 \\
Skin ulcers & 8 & 3.7 \\
Others & 35 & 16.1 \\
Associated injuries & 16 & 7.4 \\
Head trauma & 10 & 4.6 \\
Other spinal trauma & 2 & 1 \\
Extremity injuries & 3 & 1.4 \\
Brachial plexus injury & 1 & 0.5 \\
\hline
\end{tabular}

ASIA: American Spine Injury Association; DVT: deep vein thrombosis; PE: pulmonary embolism. complications, injuries to other organs associated with CST, time between trauma and surgery, and neurological status. Neurological status was classified according to the American Spine Injury Association (ASIA) ${ }^{16}$. The relative risk of complications was analyzed according to neurological status.

\section{Statistic}

Descriptive statistics were used to describe frequencies and incidences. Analytical statistics (Student's $t$-test and $\chi^{2}$ test) were used to assess the influence of time and age on the presence of complications and on the relative risk of complications according to neurological status. The level of significance was set at $\mathrm{p}<0.05$. All statistical evaluations were performed using Statistica ${ }^{\circledR}$ (version 6.1 Statsoft. Inc. 2004).

\section{RESULTS}

We identified 217 patients with severe CST between January 1997 and December 2006 in the north area of São Paulo city: 18 patients in 1997, 23 in 1998, 27 in 1999, 17 in 2000, 29 in 2001, 23 in 2002, 38 in 2003, 18 in 2004, 12 in 2005 and 12 in 2006, making the mean \pm standard deviation annual incidence of CST 21.60 \pm 8.07 . Of these patients, 43 (19.8\%) had occipitoatlanto-axial (O-C1-C2) injuries (Fig 1), while 174 (80.2\%) had subaxial (C3-C7) injuries (Fig 2). The mean age of the 217 patients was $36.75 \pm 1.06$ years, with $52.6 \%$ being 20 to 40 years old. Of the 217 patients, 191 were male $(88.0 \%)$ and 26 were female (12.0\%), making the ratio of men to women 7.35:1.

\section{Causes of trauma}

The main causes for CST were, in order of prevalence, falls (43\%), motor vehicle accidents (21\%) and diving into shallow water (12\%). Among falls, the most frequent type was falls from rooftops. Only $2.9 \%$ of the CSTs were due to gunshot injuries.

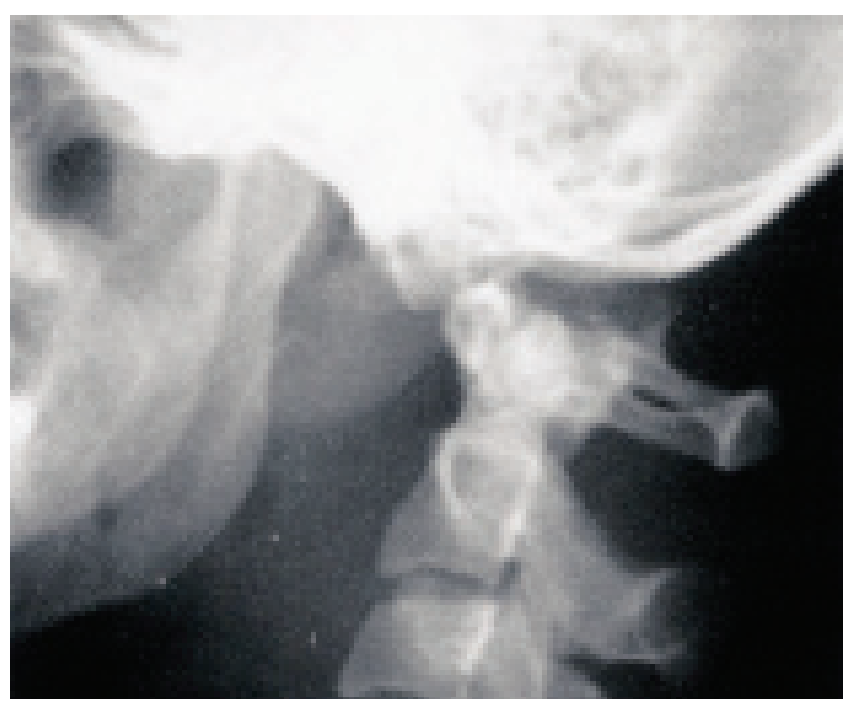

Fig 1. Atlanto-occipital type I displacement (anterior). A lateral cervical spine $x$-ray. 


\section{Clinical complications and risk factors}

Medical complications were observed in $45 \%$ of the patients, being pneumonia the most frequent $(30.2 \%$ of all complications) one. Other complications included skin pressure ulcers, urinary tract infections, deep vein thrombosis/pulmonary embolism, wound infections, acute renal failure and hematemesis (Table 1).

Risk factors predisposing for trauma were identified in $28.6 \%$ of these patients. The most important risk factors were alcoholic beverage consumption (59\%) and violence (Table 1).

\section{Associated injuries}

Associated injuries were identified in $7.5 \%$ of all patients, with head trauma (HT) representing $62.5 \%$ of all associated injuries. Of the 217 patients with CST, $4.7 \%$ had HT, identified as acute subdural hematoma, extradural hematoma, brain contusion and diffuse axonal injury. Facial trauma was the second most frequent associated injury ( $50 \%$ of all associated injuries). Other associated injuries included thoracolumbar spine trauma, tibia and femur fractures, and brachial plexus injury (Table 1).

\section{Complications}

We identified complications in 96 patients (45\%) of the 217 with CST. When we compared the two groups of patients, with and without complications, we observed no significant differences in age and time between trauma and surgical treatment (Table 2).

However, there was a significant difference between groups in neurological status. We found that patients assessed as ASIA A or B had a 2.3-fold greater relative risk of developing complications than patients assessed as ASIA C, D or E (Fig 3, Table 3).

Table 2. Age and time between trauma and surgery for patients with and without clinical complications.

\begin{tabular}{lccc} 
& $\begin{array}{c}\text { With } \\
\text { complication }\end{array}$ & $\begin{array}{c}\text { Without } \\
\text { complication }\end{array}$ & p-value* \\
Age (years) & $37.0 \pm 1.6$ & $37.0 \pm 1.4$ & 0.84 \\
Time between trauma & $11.0 \pm 1.4$ & $12.0 \pm 1.4$ & 0.73 \\
and surgery (days) & & & \\
\hline
\end{tabular}

All data reported as mean \pm standard deviation. *by Student's $t$-test.

Table 3. Association between clinical complications and American Spine Injury Association scale.

\begin{tabular}{lccc} 
& Group I & Group II & Total \\
With complication & 62 & 36 & 98 \\
Without complication & 33 & 86 & 119 \\
$\mathrm{p}<0.0001 ; \chi^{2}=28.1$ & 95 & 122 & 217 \\
\hline
\end{tabular}

Group I represents patients assessed as ASIA A or B (paraplegic patients) whereas Group II represents patients assessed as ASIA C or D or E (functional patients).

\section{Mortality}

Of the 217 patients, 33 (15.2\%) died during hospitalization. During the ten-year study period, the annual mortality rate ranged from 11 to $22 \%$. Of the patients who died, 27 (82\%) were ASIA A (complete quadriplegia), 2 (6\%) were ASIA

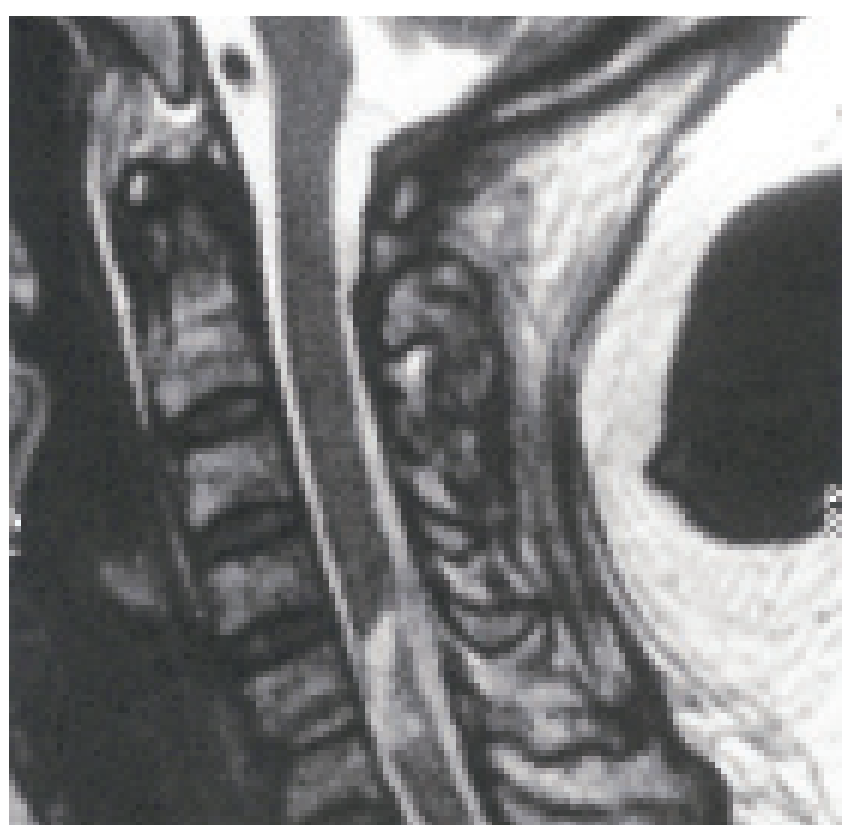

Fig 2. A T2-weight image of cervical spine in patient with central cord syndrome due to traumatic herniated disc.

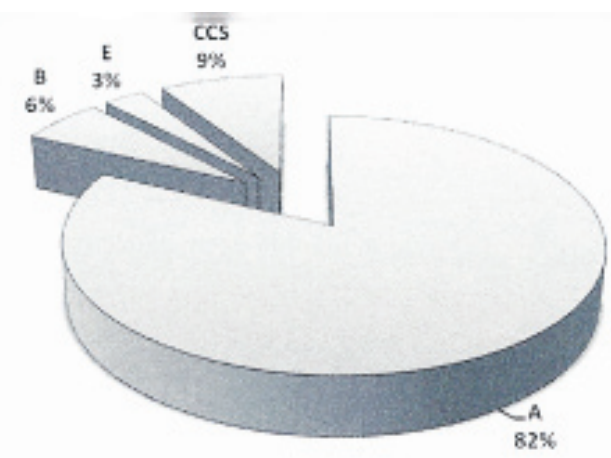

Fig 3. American Spine Injury Association classification among patients who died during hospitalization. CCS: central cord syndrome.

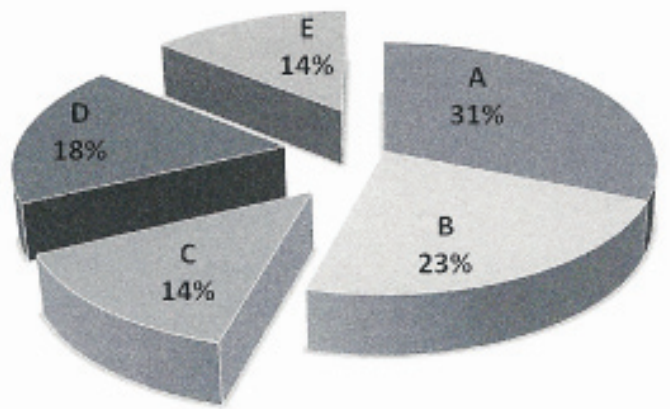

Fig 4. Clinical complications according to American Spine Injury Association classification. 
B, 3 (9\%) presented with central cord syndrome and $1(3 \%)$ was intact (Fig 4).

Of the 60 ASIA A patients, 27 (45\%) died. Patients presenting with a neurological deficit had a 16.9-fold higher risk of death than patients presenting as ASIA E $(\mathrm{p}<0.0001)$.

\section{DISCUSSION}

São Paulo City is the most populous city in the Southern Hemisphere, with an estimated population of 11.016 .703 inhabitants, and a population density of 7.247 inhabitants $/ \mathrm{km}^{2}$.

CST involves severe trauma and serious complications, with clinical status differing according to the severity of ST. The ASIA created a scale that classifies the functional (neurological) status ${ }^{16}$. This scale has proven useful in determining patient prognosis and treatment.

This study prospectively evaluated 217 patients suffering from severe CST during a ten-year period in an estimated population of 2,148,835 inhabitants. We found that the incidence of severe CST was 10.09/million population/year, an incidence lower than those documented in the United States and Europe ${ }^{17-20}$. Our series, however, included only patients who required specialized treatment, while excluding patients who did not survive the trauma at the time of the accident or in the emergency room, as well as patients who suffered light trauma without the need for specialized treatment. Thus, our series represents only patients with a real need for post-trauma treatment.

The average age of our patients was 36.75 years, with the majority (53.6\%) aged between 20 and 40 years. However, the age group showing the highest frequency of accidents may vary according to location and country of origin ${ }^{21,22}$. In agreement with most published series, we found a high male:female ration, 7.35:1. About $80 \%$ of patients showed involvement of the subaxial region, while the remainder showed involvement of the $\mathrm{O}-\mathrm{C} 1-\mathrm{C} 2$ region.

We identified risk factors predisposing for trauma in $28.6 \%$ of these patients. The primary risk factor was alcoholic beverage use, observed in $59 \%$ of patients who presented risk factors and in $17 \%$ of all patients with CST. The average age of patients who used alcoholic beverages was $40.39 \pm 2.4$ years (mean \pm standard deviation of the average), with a median of 37.8 years. The second most frequent risk factor was violence, observed in $10 \%$ of patients.
Forty-five percent of patients with CST had some type of medical complication, the most frequent being pneumonia, observed in $30.2 \%$ of patients with complications. Among the patients with pneumonia, $85 \%$ were classified as ASIA A or B and only $15 \%$ were classified as ASIA C, D or E, indicating that patients who lose the ability to walk were at higher risk for developing pneumonia. Moreover, even patients with partial deficits, but who maintain some degree of functional strength, were at lower risk of infections of the respiratory tract. Other clinical complications observed included pressure ulcers, urinary tract infections, deep vein thrombosis/ pulmonary embolism, wound infection, acute renal failure and hematemesis.

Associated injuries were identified in $7.5 \%$ of patients. The most common was HT, which represented $62.5 \%$ of all associated injuries. About $4.6 \%$ of all patients with CST had HT. Due to the mechanism of cervical trauma, the chest and head are at greater risk of associated injury.

The timing of surgical treatment and its relationship to complications have not been determined. While some studies have demonstrated that surgical treatment during the acute phase of trauma makes no difference when compared to late stage treatment, others reported that early surgical treatment worsens neurological status ${ }^{23}$. Early treatment has been found to be beneficial by stabilizing the spine and putting the patient in a position to benefit from physical therapy and rehabilitation ${ }^{24}$. When we divided patients into two groups, according to the presence or absence of clinical complications, we observed no significant differences in age and time between trauma and surgery. However, patients classified as ASIA A or B were at 2.3-fold greater risk of developing complications, and patients presenting with neurological deficit had a 16.9-fold greater risk of dying than patients presenting as ASIA E. Thus, the most important risk factor for clinical complications in patients with CST is neurological status.

In conclusion, $45 \%$ of all patients with CST had clinical complications; $7.5 \%$ of patients with CST had associated injuries in other organs; pneumonia was the most important clinical complication; alcoholic beverage use was the most important risk factor predisposing to CST; patient age and time between trauma and surgery did not influence the development of medical complications; neurological status was the most important factor in determining morbidity and mortality.

\section{References}

1. An HS. Principles and techniques of spine surgery. Baltimore: Williams \& Wilkins; 1997. p. 295-330.

2. Botelho RV, de Souza Palma AM, Abgussen CMB, Fontoura EA. Traumatic vertical atlantoaxial instability: the risk associated with skull traction. Case report and literature review. Eur Spine $J$ 2000;9:430-433.
3. Kraus JF, Franti CE, Riggins RS, Richards D, Borhani NO. Incidence of traumatic spinal cord lesions. J Chronic Dis 1975;28:471-492.

4. Kwon BK, Vaccaro AR, Grauer JN, Fisher CG, Dvorak MF. Subaxial cervical spine trauma.J Am Acad Orthop Surg 2006;14:78-89.

5. Sekhon LH, Fehlings MG. Epidemiology, Demographics, and pathophysiology of acute spinal cord injury. Spine 2001;26:S2-S12. 
6. Cavalheiro JR. Investigação epidemiológica e entrevistas domiciliares. Rev Saúde Publica 1981;15:543-550.

7. Mello MT, Fernandes AC, Tufik S. Levantamento epidemiológico da prática de atividade física na cidade de São Paulo. Rev Bras Med Esport 2000;6:61-98

8. Fielingsdorf K, Dunn RN. Cervical spine injury outcome - a review of 101 cases treated in a tertiary referral unit. S Afr Med J 2007;97:203207.

9. Liang HW, Wang YH, Lin YN, Wang JD, Jang Y. Impact of age on the injury pattern and survival of people with cervical cord injuries. Spinal Cord 2001;39:375-380.

10. Stover SL, Fine PR. The epidemiology and economics of spinal cord injury. Paraplegia 1987;25:225-228.

11. Rhee P, Kuncir EJ, Johnson L, et al. Cervical spine injury is highly dependent on the mechanism of injury following blunt and penetrating assault. J Trauma 2006;61:1166-1170.

12. Botelho RV, Abgussen CMB, Machado GCFP, et al. Epidemiologia do trauma raquimedular cervical na zona norte da cidade de São Paulo. Arq Bras Neurocirur 2001;20:64-76.

13. Holly LT, Kelly DF, Counelis GJ, Blinman T, McArthur DL, Cryer HG. Cervical spine trauma associated with moderate and severe head injury: incidence, risk factors, and injury characteristics. J Neurosurg 2002;96:285-291.

14. Reiss SJ, Raque GH Jr, Shields CB, Garretson HD. Cervical spine fractures with major associated trauma. Neurosurgery 1986;18:327-330.
15. White AA, Southwick WO, Panjabi MM. Clinical instability in the lower cervical spine. a review of past and current concepts. Spine 1976;1:15-27.

16. Maynard FM Jr, Bracken MB, Creasey G, et al. International standards for neurological and functional classification of spinal cord injury. American Spinal Injury Association. Spinal Cord 1997;35:266-274.

17. Burke DA, Linden RD, Zhang YP, Maiste AC, Shields CB. Incidence rates and populations at risk for spinal cord injury: A regional study. Spinal Cord 2001;39:274-278.

18. DeVivo MJ, Vogel LC. Epidemiology of spinal cord injury in children and adolescents. J Spinal Cord Med 2004; 27:S4-S10.

19. Harrop JS, Sharan AD, Przybylski GJ. Epidemiology of spinal cord injury after acute odontoid fractures. Neurosurg Focus 2000;8:4.

20. Ho CH, Wuermser LA, Priebe MM, Chiodo AE, Scelza WM, Kirshblum SC. Spinal cord injury medicine. 1. Epidemiology and classification. Arch Phys Med Rehabil 2007;88(Suppl):S49-S54.

21. Hearns ST, Fraser MH, Allan DB, McLean AN. Spinal injuries in Scottish mountaineers. Wilderness Environ Med 2006;17:191-194.

22. Pickett GE, Campos-Benitez M, Keller JL, Duggal N. Epidemiology of traumatic spinal cord injury in Canada. Spine 2006;31:799-805.

23. Vaccaro AR, Daugherty RJ, Sheehan TP, et al. Neurologic outcome of early versus late surgery for cervical spinal cord injury. Spine 1997;22:2609-2613.

24. Waters RL, Meyer PR Jr, Adkins RH, et al. Emergency, acute, and surgical management of spine trauma. Arch Phys Med Rehabil 1999;80:1383-1390 